Matgorzata Halicka

Wydzial Pedagogiki i Psychologi

UNIWERSYTET W BIAŁYMSTOKU

E-MAIL:MHALICKA@ONET.PL

JERZY HALICKI

Wydziae Pedagogiki i Psychologi

UNIWERSYTET W BIAEYMSTOKU

E-MAIL: JHALICKI@UWB.EDU.PL

EMILIA KRAMKOWSKA

Wydziae Pedagogiki i Psychologit

UNIWERSYTET W BIAEYMSTOKU

E-MAIL: EMILKA.KRAMKOWSKA@WP.PL

AnNa Szafranek

Instytut Prawa i Administracji

Państwowa Wyższa Szkoła Informatyki

I PrzedsięBIorczości w ŁoMży

E-MAIL: ANNASZAFRANEKO1@GMAIL.COM

\title{
MAŁŻEŃSTWO I RODZINA W OPINII STARSZYCH KOBIET DOŚWIADCZAJACYCH PRZEMOCY. NA PODSTAWIE ANALIZY AKT SĄDOWYCH W WOJEWÓDZTWIE PODLASKIM
}

\section{Wstęp}

Przemoc w małżeństwie i rodzinie jest zagadnieniem szeroko dyskutowanym w nauce, sferze politycznej, medialnej i prywatnej.

Z socjologicznego punktu widzenia - za Janem Poleszczukiem - należy powiedzieć, że rodzina jest względnie autonomicznym systemem interakcji społecznych, które odznaczają się wysokim stopniem powtarzalności. „Interakcje mają charakter całościowy - w życiu rodziny nie uczestniczy się aspektowo, w wyznaczonym miejscu i czasie, z dobrze określonymi granicami oczekiwać i powinności. W rezultacie jednostki dysponują ogrom- 
nymi zasobami wiedzy o sobie wzajemnie. (...) Z jednej strony jest to podstawa zawiązywania się silnej więzi emocjonalnej przez wykształcenie i wzajemne rozpoznawanie potrzeb i przyzwyczajeń. Z drugiej strony jednak w przypadku wystąpienia konfliktów (konfliktów preferencji, interesów, systemów motywacyjnych) powtarzalność interakcji stać się może istotnym czynnikiem eskalacji konfliktów, wzmacniania się agresji przez utrzymywanie w pamięci doznawanych krzywd, umiejętności wyrządzania krzywd dzięki wiedzy o »słabych punktach « osób, które się dobrze zna" [Poleszczuk, 2014: 22]. Powyższy fragment trafnie obrazuje specyfikę grupy pierwotnej, jaką jest rodzina oraz jej niebagatelną rolę w życiu każdego człowieka. Ponadto, proces socjalizacji, którego doświadczamy w rodzinie pochodzenia, wpływa na kształt naszego życia i relacji, jakie budujemy $\mathrm{w}$ rodzinie przez nas zakładanej.

Inspiracją do powstania niniejszego artykułu był cytat $\mathrm{z}$ wywiadu przeprowadzonego ze starszą kobietą doświadczającą przemocy ze strony męża w ramach projektu IPVoW ${ }^{1}$. Narratorka opowiadając swoją historię stwierdziła, że mimo doświadczanej przemocy nie widzi możliwości rozstania ze swoim mężem, ponieważ tak mnie po prostu wychowali, ̇̇e nalė̇y na dobre i na złe mieszkać, żyć, nic nie mówić, nie rozwodzić się.[...] Moja mama twierdziła, że tak nie powinno być, że jest dziecko, dla dziecka się poświęcić, trzeba dziecko wychować w petnej rodzinie (kobieta, 60 lat), [Halicki, Halicka, Kramkowska, 2010].

Powyższy cytat pokazuje jak wielką wartość, w opinii badanej, stanowi rodzina. Uzmysławia, że najbliższym powinno się poświęcać i podporządkowywać swoje życie, a małżeństwo winno trwać mimo doświadczanej przemocy. Pojawia się pytanie: czy oby na pewno tak powinno być? W niniejszym artykule zostaną przedstawione wypowiedzi starszych kobiet doznających przemocy małżeńskiej dotyczące uczuć, które im towarzyszą w związku z doświadczaną sytuacją. Celem artykułu będzie ukazanie specyfiki problemu przemocy, której ofiarami są osoby starsze, przejawiającej się m.in. w postawie ludzi starych wobec małżeństwa i rodziny. Ponadto, istotna będzie także odpowiedź na pytanie: czy w analizowanych przypadkach konsekwencją zgłaszania przemocy małżeńskiej do organów ścigania był rozpad małżeństwa?

1 Projekt IPVoW Intimate Partber Violence Against Older Women był realizowany w latach 20092010 przez następujących partnerów: Austria, Izrael, Niemcy, Portugalia, Polska, Węgry, Wielka Brytania. Stronę polską reprezentowali pracownicy Zakładu Socjologii Edukacji i Gerontologii Społecznej oraz Zakładu Andragogiki i Gerontologii Edukacyjnej Uniwersytetu w Białymstoku. 


\section{Metodologia}

Materiał prezentowany w niniejszym artykule stanowi część danych empirycznych zebranych podczas realizacji międzynarodowego projektu Mind the Gap! Improving Intervention in Intimate Partner Violence against Older Women program Daphne III (Mind the Gap! Poprawa jakości interwencji w przypadkach przemocy wobec starszych kobiet ze strony męża/partnera) realizowanego w latach 2011-2013². Celem projektu było wskazanie obszarów dotyczących pomocy starszym kobietom (w wieku 60+), ofiarom przemocy, które nie działają prawidłowo, a tym samym wymagają udoskonalenia. Projekt opierał się na analizie 70 akt sądowych dotyczących przemocy małżeńskiej/ partnerskiej doświadczanej przez kobiety w wieku 60 lat i więcej, które w latach 2001-2010 zostały skierowane do Sądu Rejonowego w Białymstoku na podstawie art. 207 Kodeksu Karnego. Jako metodę badawczą zastosowano analizę treści ${ }^{3}$. Posługując się kwestionariuszem wypracowanym przez partnerów projektu, jego wykonawcy ze strony polskiej zapoznawali się z materiałem dowodowym zawartym w aktach sądowych (np. zeznania pokrzywdzonych, świadków czy podejrzanych, notatki policji, ekspertyzy biegłych), zbierając tym samym informacje dotyczące ofiary, sprawcy, sytuacji przemocy oraz działań organów ścigania czy wymiaru sprawiedliwości podjętych w konkretnej sprawie. Prezentowane w artykule informacje oraz opinie na temat małżeństwa i rodziny opierają się na analizie zeznań kobiet - ofiar przemocy, które w swoich oświadczeniach poruszały powyższy temat.

Dodać również należy, że będą to wypowiedzi mieszkanek różnych części Podlasia, gdyż do Sądu Rejonowego w Białymstoku napływają sprawy z całego województwa. A podjęcie tematu przemocy wobec ludzi starych w odniesieniu do mieszkańców województwa podlaskiego jest zasadne, gdyż ogólnopolskie badania na reprezentatywnej próbie ludzi starych i tych będących na przedpolu starości, prowadzone w ramach projektu PolSenior ${ }^{4}$,

2 W projekcie Mind the Gap! brało udział 7 partnerów z 6 krajów europejskich: Austrii, Niemiec, Polski, Portugalii, Węgier, Wielkiej Brytanii. Stronę polską reprezentowali pracownicy Zakładu Socjologii Edukacji i Gerontologii Społecznej oraz Zakładu Andragogiki i Gerontologii Edukacyjnej Uniwersytetu w Białymstoku

3 Analizę przeprowadzono $2012 \mathrm{w}$ roku. Wykonawcy projektu ze strony polskiej uzyskali zgodę na analizę dokumentów sądowych, odbywało się to w budynku sądu.

4 Projekt badawczy PolSenior, realizowany od października 2007 roku do kwietnia 2012 roku, przede wszystkim był poświęcony medycznym, biologicznym, społecznym i ekonomicznym aspektom demograficznego starzenia się społeczeństwa polskiego. W badaniach wzięło udział 5695 osób, w tym 4979 osób w wieku 65 lat i więcej, i 716 badanych w wieku 55-59 lat. 
podczas których diagnozowano także zjawisko przemocy pokazały, iż na tle kraju województwo podlaskie i warmińsko-mazurskie, przedstawiają się w bardzo niekorzystnym świetle. Podczas gdy w innych częściach Polski odsetek osób starszych, które wskazały, że są ofiarami przemocy mieścił się w przedziale od 2,4\% (województwo opolskie), 3,4\% (województwo kujawsko-pomorskie), 3,9\% (województwo wielkopolskie) do 7,8\% w województwie śląskim, to w województwie podlaskim i warmińsko-mazurskim wynosił on 11,4\% (Halicka, Halicki, Ślusarczyk 2012: 502). Różnica jest zasadnicza, dlatego warto zajmować się wspomnianą tematyką i podejmować działania w celu przeciwdziałania temu zjawisku.

\section{Opis badanej próby}

$\mathrm{Z}$ punktu widzenia niniejszego artykułu istotne jest przedstawienie podstawowych cech społeczno-demograficznych sprawców i ofiar przemocy w momencie wszczęcia przez policję dochodzenia oraz danych dotyczących sytuacji przemocy pojawiających się w omawianych sprawach.

Wiek kobiet - ofiar przemocy w związku małżeńskim/partnerskim można umieścić w przedziale 60 - 81 lat. Ponad połowa pokrzywdzonych $(51,4 \%)$ to sześćdziesięciolatki, ale dość często kobiety doświadczające przemocy miały też 62, 64 czy 65 lat - każda z tych grup stanowiła 7,1\% badanych. Co więcej, 76,0\% ofiar mieszkało w mieście, pozostałe na wsi. Żadna z nich nie miała migracyjnego pochodzenia. Nie zdarzył się również przypadek, że ofiara przemocy świadczyła opiekę pielęgnacyjną wobec sprawcy, zaś 3 z nich $(4,3 \%)$ znajdowały się w sytuacji odwrotnej - otrzymywały od sprawcy opiekę. Istotne jest, iż połowa kobiet miała problemy ze zdrowiem, tym samym ich fizyczne/psychiczne zdolności do obrony przed agresją sprawcy były ograniczone. Prawie wszystkie z nich $(95,7 \%)$ otrzymywały emeryturę.

Tematyka niniejszego artykułu wymaga, by wspomnieć również i o tym, że $\mathrm{z}$ analizowanych dokumentów sądowych wynika, iż zdecydowana większość poszkodowanych kobiet zamieszkiwała ze sprawcą, pozostając z nim w związku małżeńskim. Zdarzały się jednak przypadki par będących w separacji, bądź po rozwodzie, które nadal mieszkały z podejrzanym pod jednym dachem (tabela 1). 
Małżeństwo i rodzina w opinii starszych kobiet doświadczających przemocy...

Tabela 1. Rodzaj relacji między sprawcą a ofiarą

\begin{tabular}{|c|c|c|c|}
\hline \multicolumn{2}{|c|}{ Rodzaj relacji: } & $\mathrm{N}$ & [\%] \\
\hline \multicolumn{2}{|c|}{ Małżonkowie, wspólne zamieszkiwanie } & 59 & 84,3 \\
\hline \multicolumn{2}{|c|}{ Związek partnerski, kohabitacja } & 2 & 2,9 \\
\hline \multirow{2}{*}{ Inna relacja } & $\begin{array}{c}\text { rozwód, wspólne zamiesz- } \\
\text { kiwanie }\end{array}$ & 5 & 7,1 \\
\hline & $\begin{array}{c}\text { separacja, wspólne zamiesz- } \\
\text { kiwanie }\end{array}$ & 4 & 5,7 \\
\hline \multicolumn{2}{|c|}{ Razem } & 70 & 100,0 \\
\hline
\end{tabular}

Czas trwania związku/małżeństwa ofiary i podejrzanego mieścił się w przedziale 7-57 lat, przy czym w 10 przypadkach materiał dowodowy nie był na tyle szczegółowy, bo można było oszacować czas trwania relacji. Najczęściej powtarzający się staż związku to 32, 33, 40 oraz 42 lata, każdy $\mathrm{z}$ nich stanowił 7,1\% badanej próby.

Ważne jest także podkreślenie, że ponad połowa ofiar zamieszkiwała nie tylko ze sprawcą, ale i z innymi członkami rodziny. W 55,7\% analizowanych przypadków z poszkodowaną i jej mężem/partnerem mieszkały zwykle dorosłe dzieci z wnukami, bądź matka pokrzywdzonej.

Analiza materiału sądowego pozwala również na przedstawienie profilu sprawcy przemocy wobec kobiet w podeszłym wieku. W każdym z badanych przypadków był nim mężczyzna (mąż, partner) niemający migracyjnego pochodzenia. Część aktów przemocy zaczęła się tuż po zawarciu związku małżeńskiego, lecz zdecydowana większość sprawców miała 50 lat i więcej, kiedy ofiara po raz pierwszy zgłosiła się np. na policję ujawniając, że doświadcza przemocy. Stało się to zatem po okresie wieloletniego doświadczania przemocy. W momencie ostatniego odnotowanego przez policję incydentu przemocy, który często decydował o wszczęciu postępowania, wiek sprawców mieścił się w przedziale 52-82 lata, z czego najwięcej sprawców było w wieku: 59 lat (12,9\%), 60 lat (14,3\%), 61 lat (11,4\%) i 65 lat (10\%).

Na poważne choroby somatyczne cierpiało $38,6 \%$ sprawców, $14,3 \%$ było niepełnosprawnych fizycznie, 2,9\% chorych psychicznie, a u 5,7\% zdiagnozowano demencję. Każdy $\mathrm{z}$ mężczyzn miał problem $\mathrm{z}$ nadużywaniem alkoholu. Duża część sprawców (80,0\%) otrzymywała emeryturę, a o 10,0\% z nich można powiedzieć, że byli ekonomicznie zależni od ofiar. 


\section{Uczucia dotyczące małżeństwa i rodziny w świetle zeznań pokrzywdzonych}

Jan Philipp Reemtsma analizując istotę obozów koncentracyjnych, odwołując się do koncepcji „wspomnienia przesłonowego” Zygmunta Freuda, zadał sobie pytanie: „jak to możliwe, że nasi zwyczajni ojcowie stali się mordercami?” [Reemtsma, 2011: 14]. Mając na uwadze powyższe, jak również zeznania kobiet doświadczających przemocy, można przypuszczać, że wielokrotnie zadawały sobie pytanie: jak to możliwe, że osoba mi najbliższa - mąż, stał się moim oprawcą?

Zeznania kobiet doświadczających wieloletniej przemocy ze strony męża/ partnera, spisane przez funkcjonariuszy policji czy inne osoby prowadzące dochodzenie, dostarczają informacji na temat towarzyszących im uczuć, kiedy opowiadały o rodzinie i relacjach w niej panujących. Wypowiedzi kobiet wskazują na ogromne znaczenie, jakie w ich życiu mają najbliżsi. Nic więc dziwnego, że doświadczana przez nie sytuacja wywołuje w nich strach i obawę nie tylko o siebie, ale i o innych członków rodziny. Dość często pojawiały się także uczucia wstydu, poniżenia, rozgoryczenia czy zawodu, a z drugiej strony cierpliwość i wiara w poprawę, zmianę na lepsze. Niżej zostaną zacytowane fragmenty wypowiedzi kobiet, obrazujące te kwestie.

\section{Strach}

Irena Pospiszyl wyjaśnia, że ,jeżeli kobieta nie odejdzie względnie szybko od męża, to po pewnym czasie przebywania w przemocowym związku, rodzi się specyficzny rodzaj postaw zależnościowych zarówno w psychice ofiary, jak i agresora, postaw rzadko uświadomionych, jednak głęboko osadzonych w duszy jednostki, stanowiących bardzo silny czynnik spajający traumatyczny związek" [Pospiszyl, 1994: 184-185]. A w takim związku pojawiają się różne emocje - bardzo często (jeśli nie wyłącznie) te negatywne, np. strach.

$\mathrm{W}$ dokumentach jednej $\mathrm{z}$ analizowanych spraw pojawiła się następująca wypowiedź zeznającej ofiary przemocy: syn staje $w$ mojej obronie, boję się że kiedyś zrobi mu [sprawcy] krzywdę i pójdzie za to siedzieć (...) Syn mógtby mnie przed nim obronić, ale jak mówiłam, boję się, żeby nie poszedł siedzieć. Bywa, że pije kilka dni, później kilka dni przerwy i znów od początku. Świadkami zachowania męża sa syn i sąsiadka. Nie robiłam nigdy obdukcji (kobieta 1, w związku małżeńskim od 33 lat). W podobny sposób wypowiadała się inna poszkodowana, która wyrażała obawę o zdrowie i życie swoje i dzieci: mąż mnie bije, wypędza $z$ domu, miałam obrażenia ciała 
w postaci siniaków, zadrapań. Ponadto grozi mi i dzieciom kiedy staja w mojej obronie - zabójstwem. Mąż miał nakazane leczenie odwykowe, które nie przynosi rezultatów (...) Nie odzywałam się, bo bałam się co on zrobi. Poszłam do prokuratury i złożyłam zawiadomienie, kiedy wróciłam, mąż powiedział, że mnie prokurator wyjebał. Powiedział, że się nie boi, bo mu nic nie zrobia.(...) Jestem tym zmęczona, kosztuje mnie to dużo nerwów i zdrowia. Ja się go boję, on jest nieobliczalny w swoim zachowaniu. Myślę, że w tym szale, w który wpada, może zabić. (kobieta 2, w związku małżeńskim od 36 lat). Albo wypowiedź z innej sprawy: Nie wzywam policji za każdym razem, mąż mówi wiele razy, że wszystko spali, a później mnie zabije. Mówi, że jemu jest wszystko jedno, obawiam się, że to zrobi, bo jest niezrównoważony. W nocy kiedy śpię on wstaje i bije mnie różnymi narzędziami po rękach (kobieta 5, w związku małżeńskim od 38 lat). Boje się własnego męża. Nie wzywałam policji, bo boje się interwencji, po nich jest jeszcze bardziej agresywny. Boimy się spać w nocy ponieważ nie wiemy co on może zrobić (...) Boimy się z synem siedzieć wieczorem, ponieważ wyłacza światło i grozi, że nas zabije - opowiadała inna pokrzywdzona (kobieta 6, w związku małżeńskim od 39 lat). I jeszcze jeden cytat obrazujący jak wiele negatywnych uczuć towarzyszy domownikom zamieszkującym pod jednym dachem ze sprawcą przemocy i jakie mogą być tego konsekwencje: Dzieci staja w mojej obronie, on je szarpie i kopie. Nie robiłam wcześniej żadnych badań lekarskich, ale ostatnio, po pobiciu była u lekarza i ten wydał zaświadczenie o obrażeniach. Mąż jest w I grupie inwalidzkiej bo choruje na tarczyce i cukrzycę. Pomimo chorób jest cały czas agresywny wobec mnie i dzieci. W domu jest atmosfera strachu i psychicznego wykończenia. Żyjemy w ciaglym strachu, mimo, że córka dobrze się uczyła, musiała powtarzać III klasę liceum. Gdy zgłosiła się do lekarza, on orzekt załamanie nerwowe spowodowane zła sytuacja rodzinna. Syn też bierze leki $i$ jest pod kontrola lekarza (...) Byłam na policji ze skargami na męża, ale on uważa że nie można mu nic zrobić i się nie boi. Jego zachowanie jest dla nas coraz bardziej ucią̇̇liwe, żyję $w$ strachu, że coś złego się wydarzy, ze się rano nie obudzę. Codziennie grozi mi, że mnie pobije, wygoni $z$ domu i przyprowadzi sobie konkubinę (kobieta 7, w związku małżeńskim od 35 lat).

Przytoczone wypowiedzi starszych kobiet, poszkodowanych na skutek przemocy ze strony męża, są zgodne $\mathrm{z}$ odczuciami, o których wspominały uczestniczki innego badania prowadzonego w województwie podlaskim w latach 2006-2009 przez Zakład Andragogiki i Gerontologii Wydziału Pedagogiki i Psychologii Uniwersytetu w Białymstoku, we współpracy z Komendą Wojewódzką Policji w Białymstoku oraz Miejskim Ośrodkiem 
Pomocy Rodzinie w Białymstoku, którego celem było zdiagnozowanie problemu przemocy wśród ludzi starych oraz zaplanowanie i podjęcie działań prewencyjnych, interwencyjnych i edukacyjnych ${ }^{5}$ [Halicka, Pędich, Rybaczuk, 2010: 48-49]. Analiza wywiadów pogłębionych z ofiarami przemocy wskazała, że większość starszych kobiet opowiadających o doświadczanej przemocy ze strony męża, funkcjonowała przez wiele lat w atmosferze zastraszenia, a strach o własne życie i dzieci był tak silny, że kobiety nic nie robiły ze swoją sytuacją i starały się przeczekać agresywne zachowanie męża [Halicka, Sidorczuk, 2010: 183]. A zatem zachowania i emocje opisywane przez kobiety, które postanowiły wkroczyć na drogę sądową przeciwko swemu mężowi, nie są czymś rzadko spotykanym, a wręcz przeciwnie. Co więcej, badania przeprowadzone w 2011 roku przez Obserwatorium Integracji Społecznej Regionalnego Ośrodka Polityki Społecznej (ROPS) w Białymstoku pt. Diagnoza zjawiska przemocy w rodzinie. Przemoc jako przyczyna dysfunkcji rodzin $w$ województwie podlaskim ${ }^{6}$ również potwierdzają opisywane zależności.

Praktycy biorący udział w badaniach ROPS-u „w trakcie swoich wypowiedzi opisywali świat osób doznających przemocy w rodzinie i pewne ogólne cechy, które ich zdaniem zazwyczaj charakteryzują ofiary przemocy. Najczęściej wskazywano na bezradność, strach, zatracenie poczucia godności, bezpieczeństwa i własnej wartości, a także niezdecydowanie, brak siły, mocy i wiary we własne działanie oraz bardzo niską samoocenę. W kontekście pytania o potrzeby ofiar przemocy w rodzinie badani zgodni byli, że ofiary potrzebują przede wszystkim odizolowania od sprawcy i za-

5 Realizowany projekt badawczy, finansowany przez Ministerstwo Nauki i Szkolnictwa Wyższego w Warszawie, nosił tytuł: „Przemoc wobec ludzi starych w Polsce. Na przykładzie badań środowiskowych na Podlasiu". Badania były realizowane na obszarach miejskich (3 osiedla Białegostoku) i wiejskich (3 gminy wiejskie), wybranych celowo ze względu na środowiskowe zróżnicowanie pod względem statusu społecznego, a także pod względem etnicznym i kulturowym. Badania prowadzono w 3 etapach. Najpierw był sondaż diagnostyczny wśród studentów, policjantów dzielnicowych, pracowników socjalnych, następnie badania środowiskowe wśród wybranych drogą losową 619 osób, w wieku 60 lat i więcej, mieszkających w środowiskach miejskich i wiejskich na Podlasiu. Trzeci etap badań to studium przypadku, opisujące w sposób bardziej szczegółowy nadużycia i zaniedbania wobec osób starszych. Wywiadem pogłębionym zostało objętych 47 osób - deklarowanych ofiar przemocy.

6 Badanie przeprowadzone przez ROPS miało kilka etapów - przeprowadzono m.in. analizę danych zastanych, ale również indywidualne wywiady pogłębione oraz zogniskowane wywiady grupowe (fokusy) z przedstawicielami instytucji zajmujących się problemem przemocy w rodzinie - byli to pracownicy ośrodków pomocy, interwencji kryzysowej, policji, lokalnych zespołów interdyscyplinarnych, kuratorzy sądowi, pedagodzy, przedstawiciele ochrony zdrowia i inni. 
pewnienia bezpieczeństwa" [Diagnoza..., 2012]. Ralph Linton zwraca wręcz uwagę, że potrzeba bezpieczeństwa jest, $w$ jego opinii, jedną $z$ trzech najważniejszych psychicznych potrzeb człowieka [Linton, 1975]. Można zatem powiedzieć, że zeznania starszych kobiet nie są jedynie subiektywnym opisem sytuacji, lecz jednym $\mathrm{z}$ elementów składających się na smutny obraz zjawiska przemocy w rodzinie.

\section{Wstyd}

Pia Mellody zajmująca się m.in. problematyką toksycznych związków, w tym też związków z występującą w nich przemocą wyjaśnia, że „wstyd daje nam poczucie pokory, które pozwala nam wiedzieć, że nie jesteśmy Siłą Wyższą. Zdrowy wstyd przypomina nam, że jesteśmy omylni i że musimy się uczyć odpowiedzialności" [Mellody, 1993: 91]. Jednak wstyd jest uczuciem, które podlega szkodliwym stereotypom naszej kultury. „Wolno odczuwać wstyd - pisze Mellody - ale nie powinno się o tym mówić. W rezultacie wielu z nas w ogóle nie dostrzega faktu, że życie każdego człowieka pełne jest doznań wstydu (...). Wstyd jest taką samą emocją, jak poczucie winy, ból czy radość, lecz ma pewną szczególną cechę, ponieważ dotyka naszego poczucia wartości, pozwalając nam dostrzec, że jesteśmy niedoskonali. (...) Wstyd to uczucie niezmiernie silne. Wielu ludzi sądzi, że najpotężniejszym uczuciem jakiego doświadcza człowiek jest gniew, ale niektórzy uważają że jest nim wstyd" [Mellody, 1993: 93]. Można przypuszczać, że u osób starych wstyd jest potężną emocją, dającą o sobie znać w różnych sytuacjach i wpływającą na podejmowane przez nich działania lub ich brak. Sprawdza się to w przypadku sytuacji przemocy małżeńskiej/ partnerskiej.

Analizowane zeznania kobiet potwierdziły, że wstyd znacząco oddziaływał na ich zachowania. Jedna z pokrzywdzonych mówiła: nie wzywałam policji, bo się wstydziłam. Obdukcji lekarskiej też nie robiłam, bo się wstydziłam tego, co się dzieje u mnie $w$ domu (kobieta 2, w związku małżeńskim od 36 lat). Inna z kolei zeznała: Nigdy nie wzywałam policji, wstydziłam sie dzwonić, 25 lat temu była u nas policja jak mnie pobił. Później już nie dzwoniłam (kobieta 4, w związku małżeńskim od 45 lat). Nigdy nie żaliłam się rodzinie na temat mojej sytuacji (kobieta 10, w związku małżeńskim od 25 lat) - relacjonowała kolejna kobieta i nie można wykluczyć, że czynnikiem hamującym ją przed ujawnieniem doświadczanego problemu był właśnie wstyd, gdyż nie jest łatwo mówić o tym, że krzywdzą nas osoby najbliższe. 


\section{Poniżenie}

Przywoływane wyżej badania przeprowadzone w województwie podlaskim w latach 2006-2009 wśród ludzi starych (II etap badań) wskazały, iż „zachowaniem agresywnym, które najczęściej miało miejsce w stosunku do osób starszych były kłótnie. Doświadczało ich 12,8\% wszystkich osób starszych $(\mathrm{N}=619)$. Z wyzwiskami oraz znieważaniem spotkało się 9,5\% respondentów" [Halicka, Sidorczuk, 2010: 172]. Zacytowany fragment został przytoczony celowo, gdyż ukazuje, że znieważanie przez sprawcę przemocy to kolejne odczucie doświadczane przez ofiary - również te, które zeznawały podczas dochodzenia prowadzonego przeciwko ich mężowi stosującemu zachowania agresywne.

Podczas jednej $z$ awantur mąż chwycit kij bejsbolowy $i$ chciał mnie tym kijem bić. Wtedy córka stanęła $w$ mojej obronie i mąż ja tym kijem uderzył w plecy. Krzyczy tak głośno, że nie można usiedzieć $w$ domu. Nas traktuje jak szmaty, a przy mnie podchodzi do psa i tego psa głaszcze, całuje (kobieta 2, w związku małżeńskim od 36 lat) - opowiadała jedna z kobiet. W aktach innej sprawy można było przeczytać: Ubliżał $i$ był zazdrosny o moje awanse $w$ pracy. Jak ktoś do mnie przychodził ze znajomych bądź rodziny to sie popisywat, chodził $w$ slipkach, dawat do zrozumienia, że ten ktoś jest niepotrzebny tu (...) Poniżał mnie przy obcych ludziach, mówiąc, że jestem głupia. Wykrzykiwat, że jestem nic nie warta, pochodzę ze wsi. Zwykle nic nie mówiłam, ale zdarzało się, że nie wytrzymywałam i mówiłam, że jest bestia, ale nigdy go nie wyzywałam słowami wulgarnymi (...) Dokucza mi, dzwoni do mojej rodziny i mnie oczernia (kobieta 12, w związku małżeńskim 21 lat). Kolejna $\mathrm{z}$ ofiar zeznała: mój mąż wyzywał mnie wulgarnymi słowami, poniżał (kobieta 9, w związku małżeńskim od 40 lat). Wyżej wspominano, iż praktycy biorący udział $\mathrm{w}$ badaniu prowadzonym przez ROPS $\mathrm{w}$ Białymstoku podkreślali niską samoocenę ofiar przemocy, jako wyróżniającą je cechę. Ciągłe poniżanie osoby pokrzywdzonej przez sprawcę przemocy z pewnością sprzyja zatraceniu poczucia własnej wartości.

\section{Rozgoryczenie/ Poczucie zawodu}

Kobiety doświadczające przemocy ze strony męża/ partnera w pierwszej kolejności szukają wsparcia w rodzinie. Do najbliższych osób zwracają się po radę, a w szczególnie niebezpiecznych sytuacjach również do nich kierują prośbę o schronienie [Halicka, 2012]. Podobnie było w przypadku ko- 
biet, których zeznania analizowano - jeśli nie uzyskiwały wsparcia w rodzinie, bądź otrzymywana pomoc miała charakter doraźny, zgłaszały zdarzenia wymiarowi sprawiedliwości.

Jak wskazywano powyżej, kobiety doświadczające przemocy mogą liczyć na pomoc dzieci, np. ochronę przed sprawcą $\mathrm{w}$ momencie incydentu, lecz wsparcie to łączy się ściśle ze strachem o zdrowie, a nawet życie dzieci stających w obronie matek. Z kolei inni członkowie rodziny ofiar zwykle starają się nie mieszać w ich sprawy, co jednocześnie powoduje pozostawianie kobiet samym sobie: syna nie było $w$ domu. Mąż złapał mnie za bluzkę, wciagnat do pokoju, kopnąt $w$ noge, kopnat $w$ lewa noge $w$ okolice kostki $i w$ biodro, przewrócił na tapczan i bił kułakami po całym ciele. Próbowałam się bronić, złapałam go za koszule, podrapałam po twarzy. Uwolniłam się od niego, ale zdąży mnie pobić. W tym czasie była u mnie bratowa. Jak sprawca zacząt krzyczeć obie siedziałyśmy w kuchni, bratowa słyszała $i$ widziała jak mąż mnie wyciagną do pokoju, ale nie poszła za nami, nie chciała się wtracać. Styszała mój krzyk jak mnie bit. Po bratowa przyjechał mój brat, zaproponowała, żebym pojechała $z$ nimi, bo mąż może mnie zabić. Pojechałam $z$ nimi, posiedziałam u nich, po czym mnie odwieźli. Wróciłam i zamknęłam się w swojej czesści (kobieta 4, w związku małżeńskim od 45 lat). Przerażająca i zastanawiająca jest obojętność wspomnianej bratowej. Jest ona przykładem członka rodziny, na którego osoba pokrzywdzona nie mogła liczyć. W takich przypadkach, osoba doświadczająca przemocy może odczuwać rozgoryczenie bądź zawód. Kiedy zaś pojawia się świadomość braku sił na dalsze trwanie w toksycznym związku i wsparcia ze strony rodziny, nie pozostaje nic innego jak zgłoszenie sprawy organom ścigania.

Wywiady z ofiarami przemocy zrealizowane w projekcie IPVoW wskazują, że kobiety zmagające się z przemocą ze strony męża, które otrzymują wsparcie ze strony dalszej rodziny (wyłączając własne dzieci) stanowią wyjątek [Halicka, 2012].

Przykłady wyżej omawianej sytuacji ujawniono również $\mathrm{w}$ projekcie IPVoW, w którym narratorki doświadczające przemocy ze strony mężów wskazywały, że nie mogły liczyć na rodzinę, gdyż kiedy jedna z nich zadzwoniła do siostry z prośbą o pomoc ona odłożyła słuchawkę $i$ w ogóle nie chciała ze mna rozmawiać. Sytuacja innej kobiety także nie spotkała się ze zrozumieniem jej matki, która uważała, że każdy ma swój krzyż i powinien ten krzyż dźwigać i być może tak długo, tak pod presja tej mamy tak bardzo się nie buntowałam [Halicka, 2012: 164-165]. 
Rozgoryczenie i zawód mogą pojawiać się także w sytuacjach, kiedy ofiara przemocy ma świadomość, że istnieją świadkowie, którzy mogliby jej pomóc w zerwaniu łańcucha przemocy, ale z obawy przed sprawcą, tego nie robią: mam wielu świadków, ale nie będą zeznawać bo boją się mojego męża (kobieta 8, w związku małżeńskim od 51 lat) - czytamy w zeznaniach jednej z kobiet. Inna z kolei oświadczyła: sasiad wiele razy był świadkiem stosowania przemocy, ale nie będzie zeznawat na moja korzyść, bo razem $z$ mężem pija alkohol (kobieta 11, od 20 lat po rozwodzie, nadal wspólnie mieszkają), bądź zeznania kolejnej ofiary: $z$ sąsiadami żyję dobrze, pytałam się czy zgodza się zeznawać, ale nie zgodzili się (kobieta 12, w związku małżeńskim 21 lat).

Odwołując się do powyższych przykładów trudno się dziwić, że wśród zeznających kobiet pojawiało się uczucie rozgoryczenia, bądź zawodu. Bo w sytuacjach kiedy powinny odczuwać wsparcie i poczucie bliskości ze strony najbliższych im osób, zostały pozostawione same sobie i w poczuciu osamotnienia musiały zmagać się z własnymi problemami.

\section{Cierpliwość i wiara w poprawę}

Stosowanie przemocy przez osobę najbliższą w środowisku rodzinnym, które winno dawać poczucie bezpieczeństwa i wsparcia może być traktowane w kategorii sytuacji granicznej. Anna Pawełczyńska wskazuje, iż przebywanie $\mathrm{w}$ takich warunkach zmusza do wyboru tego, co najważniejsze [Pawełczyńska, 2004]. Wypowiedzi respondentek wskazywały, że mimo przebywania w sytuacji granicznej, jaką jest wieloletnie doświadczanie przemocy ze strony męża, pokrzywdzone cierpliwie wierzyły w poprawę i miały nadzieję na zmianę zachowania oprawcy. Można więc uznać, że rodzina i małżeństwo stanowiły w ich przypadku największą wartość. Na taki stan rzeczy wskazuje fragment zeznań jednej z ofiar: kilka razy składałam zawiadomienie na policji o znęcaniu się ale za każdym razem je odwoływałam. Mąż obiecywał, że się poprawi a ja mu wierzyłam (kobieta 13, w związku małżeńskim od 32 lat). Inna z kolei dodała: nigdy wcześniej nie składałam zawiadomień, bo myślałam, że sytuacja się uspokoi (kobieta 10, w związku małżeńskim od 25 lat). Słowa kobiety wskazują na siłę przebaczenia i składanej przysięgi małżeńskiej. Michel Wieviorka nazywa taki rodzaj przebaczenia (spotykany w sytuacjach szczególnie trudnych) wybaczaniem niewybaczalnym [Wieviorka, 2011]. Należy zwrócić uwagę, iż w wielu przypadkach kobiety doświadczające przemocy ze strony mężów, bądź partnerów życiowych, próbują zapomnieć 
i mimo doznawanych krzywd - przebaczyć. Zdarzają się także przypadki usprawiedliwiania zachowania sprawcy. W wywiadach zrealizowanych w projekcie IPVoW niektóre kobiety doświadczające przemocy opowiadały, że ich zdaniem sprawca, w momencie stosowania przemocy, nie zdawał sobie sprawy ze swojego postępowania, zaś w krótkim czasie po incydencie przemocowym przepraszał ofiarę [Halicka, 2012]. Podobnie było w sprawach analizowanych w Sądzie Rejonowym w Białymstoku.

Jedna $\mathrm{z}$ kobiet zeznała, że policje na interwencje wzywałam rzadko. Zawsze chciałam się pogodzić, wszystko znosiłam. Rozmawiałam $z$ dzielnicowym w sprawie znęcania się nade mną. Mąż sie nie zmienit, jego zachowanie $z$ czasem pogarsza się. Staje się bardziej agresywny. Nie wiem co wywotuje $w$ nim agresje, ale jest coraz gorzej (kobieta 3, w związku małżeńskim od 40 lat). Powyższe słowa uzmysławiają, iż mimo cierpienia, kobieta nie tylko wierzyła z poprawę męża, ale jednocześnie starała się zrozumieć przyczynę jego złego zachowania. Najprawdopodobniej jej celem była próba wyeliminowania bodźców wpływających na eskalację przemocy ze strony męża. Oznacza to, że chęć pomocy partnerowi i poprawa sytuacji w małżeństwie stanowiły, w przypadku omawianej ofiary, większą motywację, niż dążenie do wyzwolenia się z przemocowego związku. A zatem po raz kolejny jest to przykład sytuacji wskazującej, że trwałość małżeństwa i rodziny są najważniejsze. Motywacje postępowania ofiar przemocy zdaje się potwierdzać wypowiedź kolejnej z nich, która stwierdziła: zgadzam się na mediację, nie chce męża karać, chce tylko, żeby dat mi spokój. Nie chce od męża żadnego odszkodowania za złamana noge $i$ inne krzywdy (kobieta 4, w związku małżeńskim od 45 lat).

Zeznania kobiet doświadczających przemocy wskazują, że w wielu przypadkach, kiedy decydują się na zgłoszenie sprawy na policję nie mają zamiaru ukarać sprawcy, umieścić go w zakładzie karnym, czy też uzyskać zadośćuczynienie za doznane krzywdy. One chcą jedynie uzmysłowić mu niewłaściwe postępowanie. Nie oznacza to jednak, że rezygnują z pragnienia życia bez przemocy, w zgodnym, bezpiecznym związku.

\section{Zawiadomienie o popełnieniu przestępstwa a rozpad małżeństwa}

Opisane wyżej odczucia towarzyszące przez wiele lat starszym kobietom doświadczającym przemocy małżeńskiej/partnerskiej w pewnym momencie musiały być na tyle dokuczliwe i uciążliwe, że pokrzywdzone postanowiły podjąć działania na rzecz zmiany swojej sytuacji - zgłosiły 
się na policję i wyraziły zgodę na wszczęcie postępowania karnego przeciwko mężowi/partnerowi. Nie oznacza to jednak, że nie towarzyszyły im w związku z tym różne emocje.

Analiza zgromadzonego materiału wskazała, że nie wszystkie kobiety w trakcie śledztwa charakteryzowały się postawą wskazującą na chęć ukarania sprawcy, bądź dążenia do zakończenia małżeństwa. Wprawdzie celem nieco ponad połowy badanych $(57,1 \%)$ był wyrok skazujący męża, to jednak pozostałe kobiety wykazywały postawę ambiwalentną, bądź wręcz wyrażały niechętny stosunek wobec ukarania podejrzanego. Istotne jest, iż wśród 21,4\% pokrzywdzonych zdarzyły się przypadki ofiar, które w trakcie toczącego się postępowania wycofywały oskarżenie, zgłaszały wniosek o umorzenie sprawy, bądź oświadczały, że pogodziły się z oskarżonym. Być może przekonania na temat trwałości i nierozerwalności małżeństwa wzięły górę? Zwraca uwagę fakt, że w wielu przypadkach, nawet kiedy ofiara przemocy doprowadzi do rozwodu, to jednak w kolejnych etapach zauważalny jest brak konsekwencji. Wskazuje na to przykład starszej kobiety doświadczającej wieloletniej przemocy ze strony męża, która po 5 miesiącach od rozwodu, zdecydowała się na powrót do niego [Halicka, 2012].

Analizowany materiał wskazał, iż 64 sprawy (spośród 70 analizowanych) zostały skierowane do sądu. W pozostałych przypadkach sprawy nie trafiły na wokandę, gdyż ofiary pogodziły się ze sprawcą, bądź zgłosiły wniosek o przeprowadzenie mediacji. Zeznania kobiet w trakcie toczącej się rozprawy wskazywały, iż dość często ich głównym celem było nastraszenie sprawcy, uświadomienie mu, że za swoje postępowanie grożą mu konsekwencje, bądź skierowanie go na leczenie odwykowe, nie zaś doprowadzenie do skazania i umieszczenia w zakładzie karnym. Istotne jest także, iż w 7 przypadkach (spośród przywołanych 64) sprawa została przez sąd oddalona. Powodem było złożenie przez pokrzywdzoną oświadczenia, iż pogodziła się z mężem, a jego postępowanie uległo zdecydowanej poprawie. W związku z takim stanem rzeczy kobieta nie widziała celu trwania postępowania sądowego.

Powyższe dane potwierdzają przywoływane wcześniej wypowiedzi kobiet na temat wiary w poprawę zachowania sprawcy i potrzebę uzmysłowienia mu niewłaściwego postępowania. Oznacza to, że w wielu przypadkach pokrzywdzone zgłaszając sprawę na policję nie dążyły do rozwodu, odseparowania się od męża, a pomocy sprawcy (w postaci skierowania go na przymusowe leczenie odwykowe). Motywacja w postaci utrzymania 
małżeństwa była w tych przypadkach silniejsza niż potrzeba spokoju, czy też własnego szczęścia.

\section{Podsumowanie}

Przedstawiony wyżej materiał nie pozostawia wątpliwości - małżeństwo i rodzina, to w życiu kobiet w podeszłym wieku ogromne wartości, które przedkładają nad swoje dobro. Mimo różnych emocji, których doświadczają ofiary przemocy - najczęściej tych negatywnych, przez wiele lat trwają w toksycznym związku, próbując tak długo, jak to możliwe radzić sobie $\mathrm{z}$ trudną sytuacją rodzinną. W momencie kiedy kobiety $\mathrm{w}$ podeszłym wieku - ofiary przemocy małżeńskiej/ partnerskiej nie są w stanie dłużej radzić sobie $\mathrm{z}$ towarzyszącymi im w codziennym życiu uczuciami strachu i poniżenia ze strony męża/ partnera życiowego decydują się na ujawnienia swojej sytuacji i proszą o pomoc fachowców - organy ścigania czy wymiar sprawiedliwości. Istotna jest motywacja takich działań. $\mathrm{Z}$ analizowanego materiału wynika, że z pewnością nie jest to chęć zemsty, czy ukarania oprawcy. Pokrzywdzone w wielu przypadkach nie dążą do rozwodu, a chcą jedynie, by osoby darzone przez nie wielkim szacunkiem (policja, sędziowie) przywróciły spokojne życie w ich rodzinie przez skuteczną rozmowę i konkretne działania, których celem będzie uświadomienie sprawcy, że swoim postępowaniem wyrządza krzywdę najbliższym. Można zatem powiedzieć, iż taką postawą, starsze kobiety doświadczające przemocy w małżeństwie podkreślają jak ważną instytucją jest dla nich rodzina i w sposób racjonalny adaptują się do sytuacji bez wyjścia. Zachowanie to w literaturze przedmiotu nazywane jest efektem Concorde (od nazwy samolotu latającego z Paryża do Nowego Jorku - mimo, że każdy lot generował straty, prestiż i duma nie pozwalały międzynarodowemu konsorcjum na zawieszenie lotów) lub też efektem psychologicznej pułapki. Według Jadwigi Mazur „niebezpieczeństwo wpadnięcia w psychologiczną pułapkę pojawia się wtedy, gdy jednostka zyskuje poczucie, że mimo sporego zaangażowania się nie jest prawdopodobne osiągnięcie sukcesu. Wtedy dochodzi do wniosku, że zbyt wiele zainwestowała, by teraz się wycofać. W tym momencie wchodzi do pułapki psychologicznej, a jej przejawem jest dalsze angażowanie się w związek. Wie bowiem, że starty są nieodwracalne, jest przekonana, że związek, to jej wybór, a zachowanie partnera jest przyjmowane jako mieszczące się w ramach społecznej akceptacji” [Mazur, 2005: 114-115]. Racjonalizowanie zachowań sprawcy można zatem nazwać strategią adaptującą 
pokrzywdzone do trudnej sytuacji i zmniejszającą rozmiar doznawanych krzywd i negatywnych uczuć.

\section{Bibliografia:}

Diagnoza zjawiska przemocy $w$ rodzinie $w$ województwie podlaskim. Przemoc jako przyczyna dysfunkcji rodzin, (2012) Białystok, Regionalny Ośrodek Polityki Społecznej, 2012, s. 60. http://www.rops-bialystok.pl/downloads/Diagnozaprzemocy.pdf (dostęp: 09.12.2015).

Halicka M. (2012), Przemoc wobec starszych kobiet - wywiady z ofiarami "Praca Socjalna” nr 5, s. 132-175.

Halicka M., Halicki J., Ślusarczyk P. (2012), Przemoc w stosunku do osób starszych, (w:) M. Mossakowska, A. Więcek, P. Błędowski (red.), Aspekty medyczne, psychologiczne, socjologiczne i ekonomiczne starzenia się ludzi w Polsce, Poznań, Termedia Wydawnictwa Medyczne, s. 495-509.

Halicka M., Halicki J., Kramkowska E. (2010), Raport. Badania polskie, Białystok, http://ipvow. org/images/ipvow/reports/IPVoW_Poland_polska_final.pdf (dostęp: 07.12.2015).

Halicka M., Pędich W., Rybaczuk M. (2010), Metodologia badań, (w:) M. Halicka, J. Halicki (red.), Przemoc wobec ludzi starych. Na przykładzie badań środowiskowych $w$ województwie podlaskim, Białystok, Temida 2, s. 45-67.

Halicka M., Sidorczuk A. (2010), Ludzie starzy jako ofiary przemocy w rodzinie, (w:) M. Halicka, J. Halicki (red.), Przemoc wobec ludzi starych. Na przykładzie badań środowiskowych w województwie podlaskim, Białystok, Temida 2, s. 157-193.

Linton R. (1975), Kulturowe podstawy osobowości, Warszawa, PWN.

Mazur J. (2005), Bezradność ofiar przemocy wewnątrzrodzinnej. Wprowadzenie do problematyki, (w:) Z. Gajdzica, M. Rembierz (red.), Bezradność. Interdyscyplinarne studium zjawiska $w$ kontekście zmiany społecznej i edukacyjnej, Katowice, Wydawnictwo Uniwersytetu Śląskiego, s. 98-118.

Mellody P. (1993), Toksyczne związki. Anatomia i terapia wspótuzależnienia, Warszawa, Jacek Santorski \& CO Agencja Wydawnicza.

Pawełczyńska A. (2004), Wartości a przemoc, wyd. 3, Lublin, Wydawnictwo Test.

Poleszczuk J. (2014), Rodzina - wspólnota konfliktowych interesów, „Pogranicze. Studia Społeczne", t. XXIV, s. 13-26.

Pospiszyl I. (1994), Przemoc w rodzinie, Warszawa, Wydawnictwa Szkolne i Pedagogiczne Spółka Akcyjna.

Reemtsma J. P. (2011), Zaufanie i przemoc. Esej o szczególnej konstelacji nowoczesności, Poznań, Wydawnictwo Poznańskie.

Wieviorka M. (2011), Dziewięć wykładów z socjologii, Kraków, Zakład Wydawniczy Nomos. 
SUMMARY

\section{Marriage and family in the opinion of aged women who experience violence. Based on analysis of court records in podlaskie voivodeship}

Marriage and family are very important values in the life of every human being. They play an important role in shaping the personality of its members, since the family is not without reason called as the basic unit of society. The institution of marriage and family is also a place to experience different emotions. We expect from family members interest, support and help when necessary. Sometimes, however, people who are so close to us cause pain, inflict pain, contribute to our crying or sadness. An example of the second type of situation is domestic violence. It is much more painful experience because is experienced from those who are the microcosm, are the closest to each other. In the present text we present the specifics of the problem of violence sustained by older people from the side of a spouse / partner. On the basis of the elderly women's statements - the victims - the feelings that accompany them in connection with the experienced violence was showed. Article also brings an answer to the question whether the disclosure of one experiences grievances to the authorities, affects the stability of the institutions of marriage and the family.

\section{Keywords:}

marriage, family, violence, court files 